Prepared for the U.S. Department of Energy under Contract DE-AC05-76RL01830

\title{
Plug-in Hybrid Electric Vehicle Market Penetration Scenarios
}

\author{
P. J. Balducci
}

September 2008

\section{Pacific Northwest}

NATIONAL LABORATORY 


\title{
DISCLAIMER
}

This report was prepared as an account of work sponsored by an agency of the United States Government. Neither the United States Government nor any agency thereof, nor Battelle Memorial Institute, nor any of their employees, makes any warranty, express or implied, or assumes any legal liability or responsibility for the accuracy, completeness, or usefulness of any information, apparatus, product, or process disclosed, or represents that its use would not infringe privately owned rights. Reference herein to any specific commercial product, process, or service by trade name, trademark, manufacturer, or otherwise does not necessarily constitute or imply its endorsement, recommendation, or favoring by the United States Government or any agency thereof, or Battelle Memorial Institute. The views and opinions of authors expressed herein do not necessarily state or reflect those of the United States Government or any agency thereof.

\author{
PACIFIC NORTHWEST NATIONAL LABORATORY \\ operated by \\ BATTELLE \\ for the \\ UNITED STATES DEPARTMENT OF ENERGY \\ under Contract DE-AC05-76RL01830
}

Printed in the United States of America
Available to DOE and DOE contractors from the Office of Scientific and Technical Information,
P.O. Box 62, Oak Ridge, TN 37831-0062;
ph: (865) 576-8401
fax: $(865)$ 576-5728
email: reports@adonis.osti.gov

\begin{abstract}
Available to the public from the National Technical Information Service, U.S. Department of Commerce, 5285 Port Royal Rd., Springfield, VA 22161 ph: (800) 553-6847 fax: $(703) 605-6900$ email: orders@ntis.fedworld.gov online ordering: http://www.ntis.gov/ordering.htm
\end{abstract}

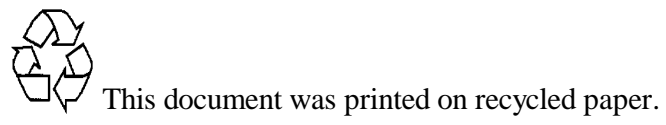


PNNL-17441

\section{Plug-In Hybrid Electric Vehicle Market Penetration Scenarios}

PJ Balducci

September 2008

Prepared for

the U.S. Department of Energy under Contract DE-AC05-76RL01830

Pacific Northwest National Laboratory Richland, Washington 99352 



\section{Summary}

This report examines the economic drivers, technology constraints, and market potential for plug-in hybrid electric vehicles (PHEVs) in the U.S. A PHEV is a hybrid vehicle with batteries that can be recharged by connecting to the grid and an internal combustion engine that can be activated when batteries need recharging. The PHEV offers the range of existing hybrid vehicles, while potentially offering the cost savings and energy benefits of electric vehicles.

When considering whether to purchase PHEVs, consumers must weigh the benefits of reduced energy consumption against the cost premium for the PHEV technology. As the cost premium is reduced over time, the PHEV will become more attractive to consumers. There still remain technical questions surrounding the ability of the battery and automotive industries to meet the demand for PHEVs given the current reliance on internal combustion technology and uncertainty associated with the battery technology required to support PHEV development.

This report attempts to address some of these questions by presenting and examining a series of PHEV market penetration scenarios. Based on input received from technical experts and industry representatives contacted for this report and data obtained through a literature review, annual market penetration rates for PHEVs were forecast from 2013 through 2045 for three scenarios. The assumptions underlying the three scenarios are highlighted in Table 1.

Table 1. PHEV Market Penetration Scenarios

\begin{tabular}{|c|c|}
\hline Scenario & Assumptions \\
\hline $\begin{array}{c}\text { Hybrid } \\
\text { Technology- } \\
\text { Based } \\
\text { Assessment }\end{array}$ & $\begin{array}{l}\text { - PHEV forecast built off existing market forecasts of hybrid technology } \\
\text { according to Greene et al. (2004) with PHEV shares of the hybrid market } \\
\text { estimated in EPRI and NRDC (2007). } \\
\text { - PHEV technology development accelerated as a result of advancements made } \\
\text { in hybrid technology. }\end{array}$ \\
\hline $\begin{array}{c}\text { R\&D Goals } \\
\text { Achieved }\end{array}$ & $\begin{array}{l}\text { - Delphi approach asking domain experts for their best judgment, given the } \\
\text { following conditions: } \\
\text { - } \$ 4,000 \text { marginal cost of PHEV technology over existing hybrid technology } \\
\text { - } 40 \text { mile all electric range } \\
\text { - } 100 \text { miles per gallon equivalent } \\
\text { - PHEV batteries meet industry standards regarding economic life and safety } \\
\text { - Tax incentives, regulations and technical standards favor PHEVs. }\end{array}$ \\
\hline $\begin{array}{c}\text { Supply } \\
\text { Constrained }\end{array}$ & $\begin{array}{l}\text { - Infusion of PHEVs in marketplace constrained by automotive and battery } \\
\text { manufacturers’ ability to meet surging demand. } \\
\text { - Existing idle off-peak capacity of electric infrastructure able to meet the } \\
\text { demand placed on it by } 73 \% \text { of light-duty vehicles in the U.S. }\end{array}$ \\
\hline
\end{tabular}

Under the Hybrid Technology-Based Assessment scenario, market penetration is forecast to reach $9.7 \%$ by 2023 and $11.9 \%$ by 2035. Under the R\&D Goals Achieved scenario, PHEV 
market penetration is forecast to ultimately reach 30\%, with 9.9\% achieved by 2023 and $27.8 \%$ reached by 2035. Finally, the Supply Constrained scenario is forecast to achieve $73 \%$ market penetration, with 26.9\% reached by 2023, and 68.4\% reached by 2035 .

Barriers to market penetration considered in this report include price, vehicle dependability, battery reliability, battery technology and supply, automotive design, re-design of the manufacturing process, supply chain management, engineering capabilities, raw material constraints, and idle off-peak capacity of electric infrastructure. These technical hurdles are considered within the framework of PHEV market penetration, which is forecast to be characterized by a logistic function or s-shaped curve. 


\section{Contents}

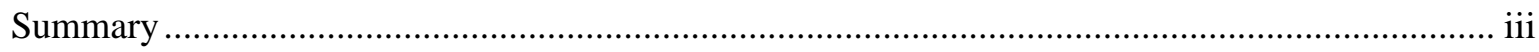

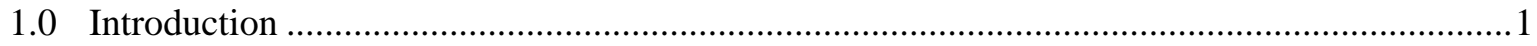

2.0 Market Penetration of Hybrid Vehicles and PHEVs ..........................................................

2.1 Hybrid Vehicle Market Penetration Forecasts ......................................................................2

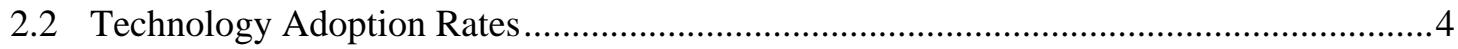

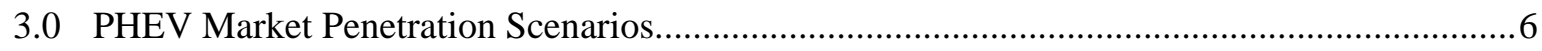

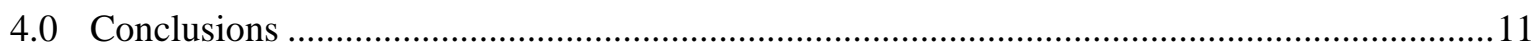

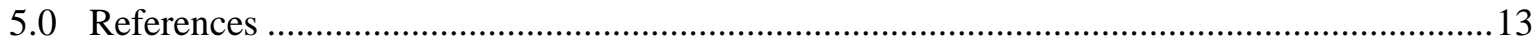

APPENDIX - Forecast Market Penetration Rates (2013-2045)....................................................14 


\section{Figures}

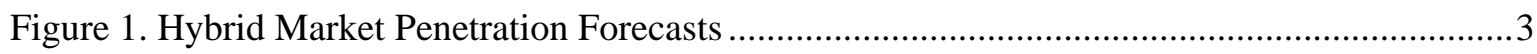

Figure 2. Quadrants in PHEV Market Penetration Curve .......................................................8

\section{Tables}

Table 1. PHEV Market Penetration Scenarios ................................................................................ iii

Table 2. EPRI and NRDC PHEV Market Penetration Forecast ......................................................4

Table 3. Time Required to Advance from $0 \%$ to 10\% Market Penetration ........................................

Table 4. Time Required to Advance from 10\% to 90\% Market Penetration .....................................5

Table 5. PHEV Market Penetration Scenarios ............................................................................6

Table 6. Industry Representatives and Technical Experts Interviewed for this Report ....................7

Table 7. PHEV Market Penetration Findings ..................................................................................10 


\subsection{Introduction}

This report examines the economic drivers, technology constraints, and market potential for plug-in hybrid electric vehicles (PHEVs) in the U.S. A PHEV is a hybrid vehicle with batteries that can be recharged by connecting to the grid and an internal combustion engine that can be activated when batteries need recharging. The PHEV offers the range of existing hybrid vehicles, while potentially offering the cost savings and energy benefits of electric vehicles. PHEVs could diversify the fuel sources used for automobiles, and enhance energy security by reducing dependence on foreign oil.

The PHEV is an effective design for reducing energy consumption. It takes advantage of idle off-peak capacity of electric infrastructure (Kintner-Meyer et al. 2007). Further, based on American travel profiles, a PHEV with a 30-mile range would enable an average of $60 \%$ of the motoring public to entirely avoid motor fuel consumption each day (Alliance Bernstein 2006). The low carbon profile of PHEVs is also attractive, although the cost and source of fuel used to generate electricity varies by region in the U.S. Thus, the advantages offered by PHEVs will vary based on where you live.

When considering whether to purchase PHEVs, consumers must weigh the benefits of reduced energy consumption against the cost premium for the PHEV technology. Because the cost premium is reduced over time, the PHEV will become more attractive to consumers. There still remain technical questions surrounding the ability of the battery and automotive industries to meet the demand for PHEVs given the current reliance on internal combustion technology and uncertainty associated with the battery technology required to support PHEV development.

This report attempts to address some of these questions by presenting and examining a series of PHEV market penetration scenarios. Based on input received from technical experts and industry representatives contacted for this report and data obtained through a literature review, annual market penetration rates for PHEVs are presented from 2013 through 2045 for three scenarios. One is considered a high-penetration scenario that is limited by supply side constraints. The assumptions underlying these scenarios are presented in Section 3, and the annual market penetration rates are presented in the Appendix.

This report is divided into four sections, the first being this introduction. The second section provides an overview of recent hybrid electric vehicle (HEV) market penetration forecasts and literature detailing historic motive power and equipment technology adoption rates. The third section presents the aforementioned PHEV market penetration scenarios. The fourth, and final, section presents study conclusions. 


\subsection{Market Penetration of Hybrid Vehicles and PHEVs}

To date, there have been very few studies assessing the market penetration of PHEVs. Hybrid vehicle market penetration, however, has been well studied. As a result of the absence of market penetration assessments for PHEVs and because the cost and financial incentives, supply constraints, and consumer acceptance issues are similar for PHEVs and hybrid vehicles, this section documents market penetration forecasts constructed for both hybrid vehicles and PHEVs.

Honda introduced the Insight in 1999, the first hybrid vehicle sold in the U.S. market. In 2000, Toyota introduced the Prius, although it has offered the vehicle in Japan since 1997. In 2000, only 6,479 hybrids were sold in the U.S. In recent years, as motor fuel prices have escalated and concerns over the environmental impacts of auto emissions have moved to the forefront of public policy debate, hybrid vehicle sales have grown at a rapid pace, reaching 324,318 in 2007. ${ }^{1}$ Note that 2007 sales figures have not been fully reported for several hybrid models, including the Ford Escape, Lexus LS 600h, Mercury Mariner, Saturn Vue, Toyota Camry, and Toyota Highlander. Even with the robust growth in HEV sales, HEVs represented only $2.3 \%$ of light-duty vehicle sales in 2007.

\subsection{Hybrid Vehicle Market Penetration Forecasts}

Recent market assessments have shown that motor fuel economy is the number one reason consumers give for purchasing hybrid vehicles (78\%), while the ability to reduce air pollution is the second most cited reason (54\%). The top consumer concerns associated with hybrid vehicles are insufficient power (34\%), price (27\%) and vehicle dependability (24\%). More specifically, dependability surrounding battery technology was a concern for $12 \%$ of those surveyed. In spite of these concerns, $15.2 \%$ of those surveyed indicated that, for their next vehicle purchase, they would be likely to buy or definitely would buy a hybrid vehicle. Those who indicated that they would definitely buy a hybrid vehicle totaled $4.3 \%$ of the respondents (Greene et al. 2004).

The findings of numerous recent hybrid vehicle market forecasts are presented in Figure 1 . The JD Power and Associates hybrid vehicle market assessment was most conservative, forecasting a penetration rate of just over 3\% by 2013 (Greene et al. 2004). Other more recent market assessments, including those performed by Greene et al. (2004), Alliance Bernstein (2006), Morgan Stanley, and the Electric Power Research Institute (EPRI) and Natural Resources Defense Council (EPRI and NRDC 2007) have been more aggressive, with market penetration rates of between $10 \%$ and $16 \%$ forecast by 2015 .

\footnotetext{
${ }^{1}$ http://www.electricdrive.org/index.php?tg=articles\&topics=7
} 


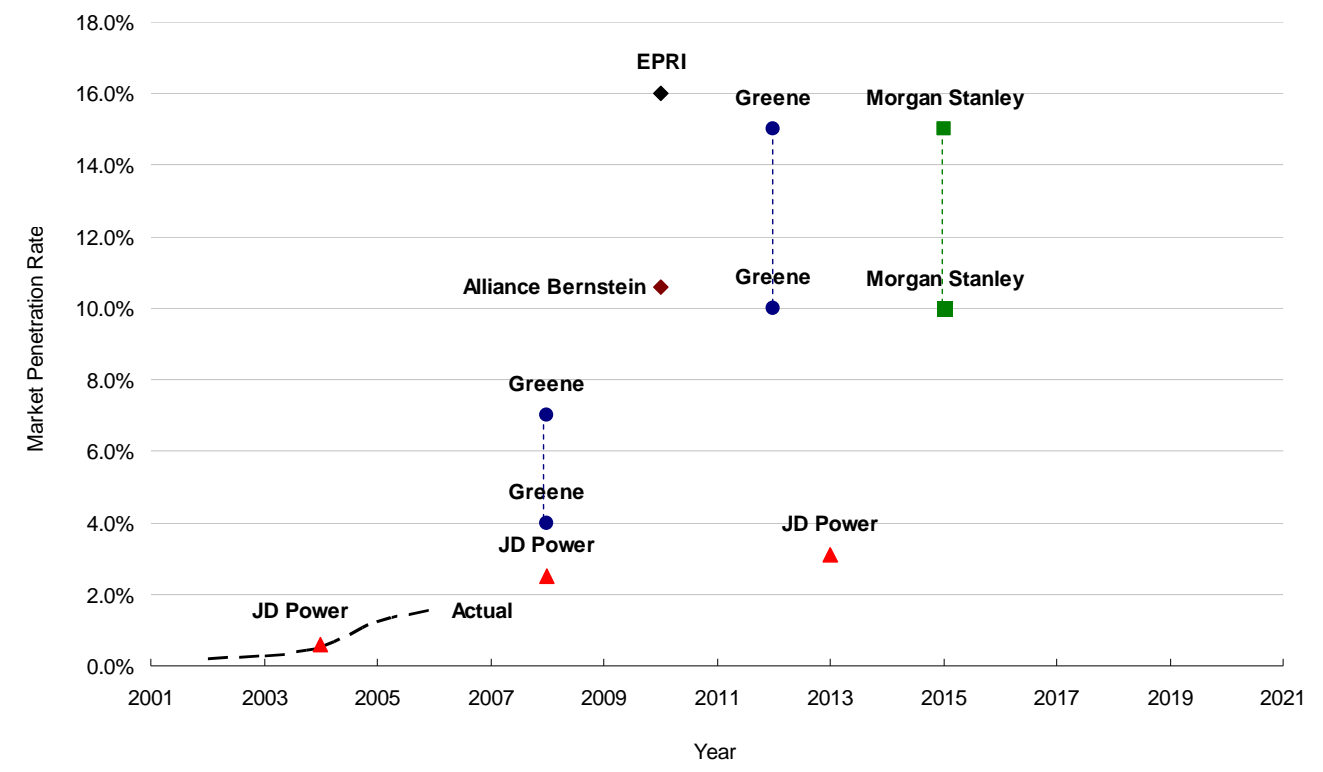

Source: Adapted from Greene et al. (2004)

Figure 1. Hybrid Market Penetration Forecasts

Greene et al. (2004) used a nested multinomial logit consumer choice model to examine numerous scenarios associated with hybrid and diesel vehicle purchases. These scenarios covered multiple time periods and assumptions regarding competing technologies. Based on the scenarios that considered future demand for both diesel and hybrid vehicle technologies, hybrids were forecast to capture between $4 \%$ and $7 \%$ of the light-duty vehicle market in 2008 and between $10 \%$ and $15 \%$ of the market in 2012. The long-run potential market share for hybrid vehicles was estimated at $16.5 \%$.

EPRI and NRDC (2007) forecast sales for hybrid vehicles, conventional internal combustion vehicles, and PHEVs over an extended time period (through 2050). Market penetration, in turn, is used to assess the impact of technology transformation on the U.S. energy sector and vehicle emissions. EPRI and NRDC forecasts of hybrid and PHEV market penetration are based on "choice based market modeling of customer preference between PHEVs, HEVs, and conventional vehicle options.” The consumer choice model is not documented in the EPRI and NRDC report. The EPRI and NRDC model forecasts robust growth in PHEV market penetration, with PHEVs reaching 37\% of new vehicle purchases in 2020 and 52\% by 2035. Table 2 presents the findings of the EPRI and NRDC study, which forecasts a PHEV market penetration rate of $62 \%$ by 2050 under the medium PHEV fleet penetration scenario. 
Table 2. EPRI and NRDC PHEV Market Penetration Forecast

\begin{tabular}{|l|l|c|c|c|}
\hline \multicolumn{2}{|c|}{$\begin{array}{c}2050 \text { New Vehicle Market Share } \\
\text { by Scenario }\end{array}$} & \multicolumn{3}{|c|}{ Vehicle Type } \\
\cline { 2 - 4 } & Conventional & Hybrid & Plug-In Hybrid \\
\hline $\begin{array}{l}\text { PHEV Fleet } \\
\begin{array}{l}\text { Penetration } \\
\text { Scenario }\end{array}\end{array}$ & $\begin{array}{l}\text { Low PHEV Fleet } \\
\text { Penetration }\end{array}$ & $56 \%$ & $24 \%$ & $20 \%$ \\
\cline { 2 - 5 } & $\begin{array}{l}\text { Medium PHEV } \\
\text { Fleet Penetration }\end{array}$ & $14 \%$ & $24 \%$ & $62 \%$ \\
\cline { 2 - 5 } & $\begin{array}{l}\text { High PHEV Fleet } \\
\text { Penetration }\end{array}$ & $5 \%$ & $15 \%$ & $80 \%$ \\
\hline
\end{tabular}

Source: EPRI and NRDC (2007).

In a market study recently completed by Morgan Stanley Research, U.S. hybrid electric vehicle demand is forecast to grow to 1.2 million units in 2015 and nearly 2 million units by 2020 . Morgan Stanley forecasts that the first PHEV will be introduced in the marketplace by 2010, and U.S. PHEV market demand will reach 250,000 units by 2015 and 1 million units by 2020 (Morgan Stanley 2008).

\subsection{Technology Adoption Rates}

Technology adoption rates in the transportation sector have most commonly taken the shape of an s-shaped curve or logistic function. From initial introduction to the first point of inflection in the curve, market penetration has generally increased from between $0 \%$ and $10 \%$ of its ultimate market saturation point. Historically, technology adoption rates from $0 \%$ to $10 \%$ were driven by the need to reduce externalities associated with the existing technology, while growth from 10\% to $90 \%$ was driven by cost reduction and system efficiencies (Hollinshead et al. 2005).

From initial commercial introduction to $10 \%$ market penetration, new technologies evolve, transform, and become viable in the marketplace. Initially, skeptical investors and manufacturers are hesitant to adopt the new technology, leading to a lack of capital investment and resources required to nurture and refine the new technology. This section of the market penetration curve can take many years to traverse, as noted in Table 3 (Hollinshead et al. 2005).

Table 3. Time Required to Advance from 0\% to 10\% Market Penetration

\begin{tabular}{|l|c|}
\hline \multicolumn{1}{|c|}{ Technology Substitution } & Time \\
\hline Sailing ship to steam ship & 19 years \\
\hline Horse cab to internal combustion engine cab & $14-18$ years \\
\hline Steam locomotive to diesel-electric locomotive & $15-19$ years \\
\hline Source: Hollinshead et al. (2005).
\end{tabular}

Over time, technologies become more efficient and cost effective when compared to competing alternatives, and supply chains build up to handle surging demand. At this stage in the technology adoption process, the market opens up for the new technology, and penetration 
increases rapidly from $10 \%$ to $90 \%$ of its ultimate adoption rate. This section of the s-shaped market penetration curve is characterized by an extreme upward slope. When considering motive power in transportation (e.g., horse tram to electric, reciprocating steam engine to turbine, horse cab to internal combustion engine), Hollinshead et al. (2005) found great consistency in the time required to move from $10 \%$ to $90 \%$ market penetration, with each new technology taking 12 years to move along this section of the s-shaped curve (Table 4).

Table 4. Time Required to Advance from $10 \%$ to $90 \%$ Market Penetration

\begin{tabular}{|l|c|}
\hline \multicolumn{1}{|c|}{ Technology Substitution } & Time \\
\hline Transportation infrastructure (canals, railways, roads, airways) & 100 years \\
\hline Primary energies (wood, coal, oil, methane) & 100 years \\
\hline Sailing ship to steam ship & 80 years \\
\hline Electrical power in factories & 37 years \\
\hline $\begin{array}{l}\text { Motive power in transportation } \\
\text { - horse tram to electric }\end{array}$ & 12 years \\
- horse to auto & \\
- steam locomotive to diesel-electric & \\
\hline Automobiprocating steam engine to turbine & 12 years \\
\hline
\end{tabular}

Source: Hollinshead et al. (2005).

Historic technology adoption rates in the transportation sector were considered when developing the scenarios presented in the next section of this report. Input received from the industry representatives and technical experts contacted for this report was consistent with the historic adoption rates and technology assessments presented in Hollinshead et al. (2005). 


\subsection{PHEV Market Penetration Scenarios}

This report considers three PHEV market penetration scenarios. For this report, market penetration is defined as the share of new light-duty vehicle sales comprising PHEVs. Each scenario is outlined in Table 5. In the Hybrid Technology-Based Assessment scenario, PHEV forecasts are built off the long-run hybrid forecasts prepared in Greene et al. (2004). In this scenario, PHEV technology adoption is accelerated as a result of lessons learned through development of hybrid technology, and the ultimate PHEV share of the hybrid market is based on the penetration definition by EPRI and NRDC (2007).

The second scenario assumes that the major goals specified in the U.S. Department of Energy's "Plug-In Hybrid Electric Vehicle R\&D Plan” are achieved and the tax incentives and positive regulatory environment governing current hybrid technologies are extended to PHEVs (U.S. DOE 2007). Beginning with the assumption that the goals specified in the R\&D plan are reached, a two-round Delphi analysis was performed in which industry experts were asked for plausible and defensible penetration curves. Following an initial consultation, penetration curves were constructed and sent back to the Delphi panel for review and comment. Penetration rates are presented in the Appendix.

Table 5. PHEV Market Penetration Scenarios

\begin{tabular}{|c|c|}
\hline Scenario & Assumptions \\
\hline $\begin{array}{c}\text { Hybrid } \\
\text { Technology- } \\
\text { Based } \\
\text { Assessment }\end{array}$ & $\begin{array}{l}\text { - PHEV forecast built off existing market forecasts of hybrid technology } \\
\text { according to Greene et al. (2004) with PHEV shares of the hybrid market } \\
\text { estimated in EPRI and NRDC (2007). } \\
\text { - PHEV technology development accelerated as a result of advancements made } \\
\text { in hybrid technology. }\end{array}$ \\
\hline $\begin{array}{c}\text { R\&D Goals } \\
\text { Achieved }\end{array}$ & $\begin{array}{l}\text { - Delphi approach asking domain experts for their best judgment, given the } \\
\text { following conditions: } \\
\text { - } \$ 4,000 \text { marginal cost of PHEV technology over existing hybrid technology } \\
\text { - } 40 \text { mile all electric range } \\
\text { - } 100 \text { miles per gallon equivalent } \\
\text { - PHEV batteries meet industry standards regarding economic life and safety } \\
\text { - tax incentives, regulations and technical standards favor PHEVs. }\end{array}$ \\
\hline $\begin{array}{c}\text { Supply } \\
\text { Constrained }\end{array}$ & $\begin{array}{l}\text { - Infusion of PHEVs in marketplace constrained by automotive and battery } \\
\text { manufacturers' ability to meet surging demand. } \\
\text { - Existing idle off-peak capacity of electric infrastructure able to meet the } \\
\text { demand place on it by } 73 \% \text { of light duty vehicles in the U.S. Note that while } \\
\text { off-peak capacity will be expected to change over the next } 25 \text { years, no } \\
\text { assumptions have been made regarding the extent to which infrastructure } \\
\text { investment will meet future demand for energy. }\end{array}$ \\
\hline
\end{tabular}


The final scenario (Supply Constrained) is based on the assumption that, with sufficiently high consumer demand for PHEVs generated through various financial incentives and national energy security priorities and mandates, ultimate market penetration would be limited only by the idle off-peak capacity of electric infrastructure to meet the demand placed on it by light-duty vehicles, and near-term penetration would be limited only by the battery and automotive industries' ability to meet the surging demand. The ultimate market penetration cap is set at $73 \%$ of light-duty vehicle sales based on the findings of Kintner-Meyer et al. (2007). Near-term adoption rates are limited based on input received by the Delphi panel.

The R\&D Goals Achieved and Supply Constrained scenarios were presented to a group of industry representatives and technical experts during a series of interviews. The objectives of the interviews were to determine:

- The timing of technology adoption milestones (e.g., introduction of a commercially viable PHEV, $10 \%$ market penetration, 90\% market penetration)

- Barriers to commercial introduction of PHEVs

- Constraints in the supply chain that could slow market penetration

- Market penetration rates.

The experts and industry representatives contacted for this study are identified in Table 6.

Table 6. Industry Representatives and Technical Experts Interviewed for this Report

\begin{tabular}{|l|c|}
\hline \multicolumn{1}{|c|}{ Representative/Expert } & Company \\
\hline Joe Adiletta & A123 Systems \\
\hline Ralph Brodd & Broddarp of Nevada \\
\hline David Greene & Oak Ridge National Laboratory \\
\hline Felix Kramer & CalCars \\
\hline Katherine Mack & Rose Electronics \\
\hline Mark Mehall & Ford \\
\hline Bill Reinert & Toyota \\
\hline Ron Turi & Lithium Technology Corporation \\
\hline Rick Woodbury & Commuter Cars Corporation \\
\hline Nick Zielinski & General Motors \\
\hline
\end{tabular}

An illustrative s-shaped market penetration curve is presented in Figure 2. For each quadrant identified in the figure, respondents were asked to identify barriers addressed during the timeframe examined and the activities undertaken to move to the next quadrant. The quadrants were defined as follows: 
- Quadrant I: The period leading up to the introduction of a commercially viable PHEV

- Quadrant II: Early stages of commercialization with an evolving technology and new battery and automotive manufacturing facilities being brought on-line

- Quadrant III: Ramp-up of PHEV production with a mature technology and a significant expansion in the capacity to manufacture and distribute PHEVs

- Quadrant IV: Ultimate constraints on PHEV market penetration (e.g., idle off-peak capacity).

Those interviewed for this study were encouraged to provide data and literature to support conclusions whenever possible and were asked to assume that PHEV market penetration could be characterized by a logistic function.

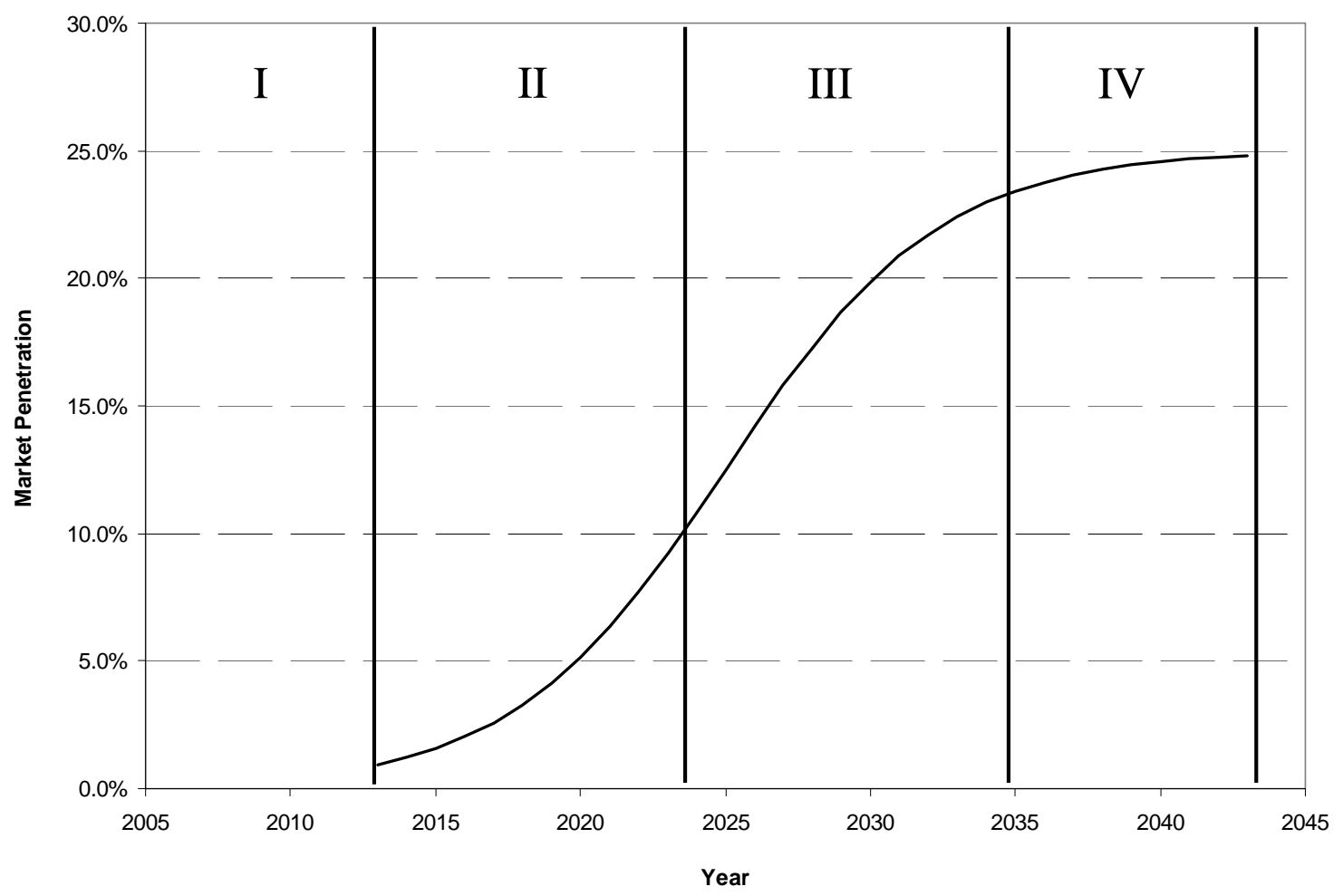

Figure 2. Quadrants in PHEV Market Penetration Curve

The principal constraint in Quadrant I cited by each respondent, with the exception of one representative of a battery manufacturer, was existing battery technology. Technical hurdles as they relate to battery technology include: depth of discharge, energy density, durability of the battery, life of the battery, intellectual property (IP) issues relating to lithium ion batteries, battery size and weight, and the cost to manufacture the batteries required to power PHEVs. The U.S. battery industry was also viewed as underdeveloped and not prepared for a significant ramp-up in demand for PHEV batteries. 
Those surveyed for this report noted several other constraints to initial commercial deployment, including vehicle design, software development, and resolution of IP issues. During the vehicle design process, auto manufacturers will be faced with several challenging issues, including:

- How to incorporate the weight and space demands of the battery system

- How to design instruments to monitor the charge and temperature of the battery system

- How to incorporate the generator, blowers, pumps, and other elements into the design process

- How to build the battery system into the manufacturing process

- How to re-tool the plant to most efficiently assemble the PHEV

- How to maintain vehicle safety.

All of the aforementioned elements must be considered within the context of cost. Based on input received from those interviewed for this study, the segment of the market penetration curve represented in Quadrant I is assumed to take place during the 2008-2013 time period, with the first commercially viable PHEV being introduced in 2013. Experts viewed 2013 as a reasonable timeframe for initial mass marketing in spite of some recent reports that suggest PHEVs may hit the market sooner than previously anticipated. ${ }^{1}$

The time period represented by Quadrant II will be characterized by transition to a sophisticated technology in the most efficient manner battery and automobile manufacturers can devise. The time period included in Quadrant II is expected to cover the 10 years following initial commercial introduction (2013-2023). During this phase of development, engineering capabilities will be developed. The supply chain will begin to evolve with suppliers of everything from power transistors to high density circuit boards being brought on-line. Battery manufacturers will need to make significant investments while expanding facilities to manufacture and assemble new battery systems. Battery testing facilities will expand to test the new systems.

During this period, companies will be investigating and testing different suppliers. Battery chemistries will be tested and refined. HEVs are currently thought to be in this stage of development. For example, the Toyota Prius has, in the past, been equipped with nickel metal hydride batteries. In recent years, however, Toyota has expressed interest in moving toward a lithium ion battery pack for the Prius. Because of safety concerns, the third generation Toyota Prius is not expected to use lithium ion batteries; however, lithium ion remains an option for the fourth and fifth generation battery systems currently under development.

During this period, manufacturers will be faced with a number of issues raised by consumers, including those relating to power, price, reliability, safety, and performance. How these issues are handled from the standpoint of marketplace perception will also play a role in the success of the PHEV.

\footnotetext{
${ }^{1}$ http://www.bloomberg.com/apps/news?pid=20601101\&sid=akRq_GCaGMRE\&refer=japan
} 
Quadrant III (2023-2035) of the market penetration curve is expected to be characterized by a rapid expansion in PHEV market penetration, as increasing numbers of automotive assembly lines and battery manufacturing facilities are brought on-line. Raw material constraints, if any, will be revealed during this phase. Quadrant III is also expected to be characterized by technology enhancements and cost reductions, thus spurring on consumer demand and acceptance. Even when considering only supply constraints, respondents noted that auto manufacturers are typically on a 5 to 7 year design cycle. Thus, models currently under development would be completed, even if an exceptional battery was introduced into the marketplace, and PHEV development would wait until the next design cycle. Of course, modifications to existing models (e.g., Toyota Prius) would not require the 5 to 7 year time lag.

Quadrant IV (2035-2045) will be characterized by continued but slowed growth in PHEV market penetration. During this period, the technology will have reached its maturity and market saturation will be achieved. In the Supply Constrained scenario, market penetration reaches 73\% in recognition of constrained existing idle off-peak capacity of electric infrastructure. In the R\&D Goals Achieved scenario, additional constraints are placed on ultimate market penetration, including consumer needs and preferences and competing technologies (e.g., diesel, hybrid vehicles).

Based on the input received from the technical experts and industry representatives contacted for this study, as well as the data obtained and examined through the literature review, market penetration rates for the three scenarios outlined previously in this section of the report are presented in Table 7. Under the Hybrid Technology-Based Assessment scenario, ultimate market penetration is forecast to reach $9.7 \%$ by 2023 and $11.9 \%$ by 2035 . Under the R\&D Goals Achieved scenario, PHEV market penetration is forecast to ultimately reach $30 \%$, with $9.9 \%$ achieved by 2023 and 27.8\% reached by 2035. Finally, the Supply Constrained scenario is forecast to achieve $73 \%$ market penetration, with $26.9 \%$ reached by 2023 and $68.4 \%$ reached by 2035. Forecast annual market penetration rates are presented in the Appendix.

Table 7. PHEV Market Penetration Findings

\begin{tabular}{|l|c|c|c|}
\hline & \multicolumn{3}{|c|}{ Market Penetration Rates for Each Scenario } \\
\hline Period Ending & $\begin{array}{c}\text { Hybrid Technology- } \\
\text { Based Assessment }\end{array}$ & R\&D Goals Achieved & Supply Constrained \\
\hline 2013 & -- & -- & -- \\
\hline 2023 & $9.7 \%$ & $9.9 \%$ & $26.9 \%$ \\
\hline 2035 & $11.9 \%$ & $27.8 \%$ & $68.4 \%$ \\
\hline 2045 & $11.9 \%$ & $29.8 \%$ & $72.7 \%$ \\
\hline $\begin{array}{l}\text { Total Market } \\
\text { Penetration }\end{array}$ & $11.9 \%$ & $30.0 \%$ & $73.0 \%$ \\
\hline
\end{tabular}

It is important to note that as conventional spark ignition motors continue to improve, diesel engines grow in the U.S. marketplace, HEVs continue to evolve, and vehicles become lighter and smaller, the PHEV will face increasing competition from these other alternative technologies. Thus, it is far too early to declare a winner among these competing technologies and to the extent that these or other as yet undeveloped technologies gain favor among consumers, PHEV market penetration rates could be significantly dampened. 


\subsection{Conclusions}

There are a number of conclusions that can be drawn from the research presented in this report:

- The number one reason consumers cite for purchasing a hybrid vehicle is motor fuel economy (78\%). The second most common reason for purchasing a hybrid is the ability to reduce motor vehicle emissions (54\%). Reasons given for not purchasing hybrid vehicles included insufficient power (34\%), price (27\%), and vehicle dependability (24\%).

- Several recent market assessments have forecast robust growth in hybrid sales, with penetration rates in the range of $10 \%$ to $15 \%$ by 2015 .

- One recent market assessment conducted by EPRI and NRDC (2007) forecast PHEV penetration rates of $62 \%$ by 2050 .

- Historic technology adoption rates for motive power in the transportation sector have followed logistic functions with the time required to advance from $0 \%$ to $10 \%$ market penetration ranging from 14 to 19 years and the time required to advance from $10 \%$ to $90 \%$ market penetration consistently totaling 12 years.

- In the short-term, the most significant barrier to PHEV commercialization revolves around battery technology. Technical hurdles as they relate to battery technology include: depth of discharge, energy density, durability of the battery, life of the battery, IP issues relating to lithium ion batteries, battery size and weight, and the cost to manufacture the batteries required to power PHEVs.

- Once battery technology for PHEVs is finally developed, additional constraints will take the form of limited engineering capabilities, existing vehicle design cycles, the need to design and construct new manufacturing facilities, the need to develop the domestic battery industry, and raw material constraints.

- Three penetration scenarios were analyzed and their results can be summarized as follows:

o Case 1: Hybrid Technology-Based Assessment:

- Based on estimates of hybrid market penetration rates presented in Greene et al. (2004) and PHEV shares of the hybrid market estimated in EPRI and NRDC (2007), the total PHEV market share of the light-duty vehicle market is estimated to reach only $11.9 \%$.

- The principal barriers to hybrid vehicle market penetration cited in Greene et al. (2004) included insufficient power, price, vehicle dependability and 
battery reliability. These market barriers were developed through consumer surveys conducted by J.D. Power and Associates.

o Case 2: R\&D Goals Achieved. Experts and industry representatives contacted for this study concluded that:

- Even if the goals stated in the Plug-In Hybrid Electric Vehicle R\&D plan are achieved, PHEVs will not capture more than $30 \%$ of the light-duty vehicle market. Reasons for limiting PHEV market penetration include recent advancements in alternative technologies including diesel, and consumer acceptance hurdles resulting from individuals with driving profiles (e.g., haul heavy equipment, long commutes, commutes on highways) that would not take full advantage of the benefits associated with PHEVs.

- $\quad$ The first commercially viable PHEV is expected to be introduced by 2013 .

- The initial phase of PHEV development will continue through 2023 before ramping up and reaching the vast majority of its market potential by 2035.

o Case 3: Supply Constrained. Market penetration constrained only by idle offpeak capacity of electric infrastructure and automotive and battery manufacturers' ability to meet surging demand:

- In a scenario where PHEV demand surges, market penetration would still be characterized by a logistic function (s-shaped curve) as a result of technical hurdles relating to battery and automotive technology and manufacturing.

- With market penetration constrained only by the ability of the battery and automotive industries to meet surging demand and the presence of offpeak capacity, PHEV sales as a percentage of total light-duty vehicle sales would reach $26.9 \%$ by 2023 .

- PHEV market penetration would reach $73 \%$ by 2045 but could not exceed that level without expanding the off-peak capacity of electric infrastructure. 


\subsection{References}

Alliance Bernstein. 2006. "The Emergence of Hybrid Vehicles: Ending Oil’s Stranglehold on Transportation and the Economy.” New York.

Electric Power Research Institute and Natural Resources Defense Council. 2007.

"Environmental Assessment of Plug-In Hybrid Electric Vehicles - Volume 1: Nationwide Greenhouse Gas Emissions.” Palo Alto, California.

Greene, D., K. Duleep, and W. McManus. 2004. "Future Potential of Hybrid and Diesel Powertrains in the U.S. Light-Duty Vehicle Market.” Oak Ridge National Laboratory. Oak Ridge, Tennessee.

Hollinshead, M., C. Eastman, and T. Etsell. 2005. "Forecasting Performance and Market Penetration of Fuel Cells in Transportation.” Fuel Cells Bulletin, Volume 2005, Issue 12, December 2005, pg. 10-17.

Kintner-Meyer, M., K. Schneider, and R. Pratt. 2007. "Impacts Assessment of Plug-In Hybrid Vehicles on Electric Utilities and Regional U.S. Power Grids - Part 1: Technical Analysis." In Electric Utilities Environmental Conference. $10^{\text {th }}$ Annual EUEC Conference \& Expo. Clean Air, Mercury, Global Warming \& Renewable Energy, vol. 1. Tucson, Arizona.

Morgan Stanley. 2008. “Plug-in Hybrids: The Next Automotive Revolution.” New York.

U.S. Department of Energy, Office of Energy Efficiency and Renewable Energy. 2007. "PlugIn Hybrid Electrical Vehicle R\&D Plan.” Washington, D.C. 


\section{APPENDIX - Forecast Market Penetration Rates (2013-2045)}




\section{Appendix - Forecast Market Penetration Rates (2013-2045)}

\begin{tabular}{|c|c|c|c|}
\hline Year & \begin{tabular}{l|} 
Hybrid Technology \\
Based Assessment
\end{tabular} & R\&D Goals Achieved & Supply Constrained \\
\hline 2013 & $0.3 \%$ & $1.0 \%$ & $2.8 \%$ \\
\hline 2014 & $0.6 \%$ & $1.3 \%$ & $3.6 \%$ \\
\hline 2015 & $0.9 \%$ & $1.6 \%$ & $4.6 \%$ \\
\hline 2016 & $1.4 \%$ & $2.1 \%$ & $5.9 \%$ \\
\hline 2017 & $2.2 \%$ & $2.7 \%$ & $7.5 \%$ \\
\hline 2018 & $3.2 \%$ & $3.4 \%$ & $9.6 \%$ \\
\hline 2019 & $4.5 \%$ & $4.3 \%$ & $12.1 \%$ \\
\hline 2020 & $5.9 \%$ & $5.4 \%$ & $15.0 \%$ \\
\hline 2021 & $7.4 \%$ & $6.7 \%$ & $18.5 \%$ \\
\hline 2022 & $8.7 \%$ & $8.2 \%$ & $22.5 \%$ \\
\hline 2023 & $9.7 \%$ & $9.9 \%$ & $26.9 \%$ \\
\hline 2024 & $10.5 \%$ & $11.8 \%$ & $31.6 \%$ \\
\hline 2025 & $11.0 \%$ & $13.8 \%$ & $36.5 \%$ \\
\hline 2026 & $11.3 \%$ & $15.8 \%$ & $41.4 \%$ \\
\hline 2027 & $11.5 \%$ & $17.8 \%$ & $46.1 \%$ \\
\hline 2028 & $11.7 \%$ & $19.7 \%$ & $50.5 \%$ \\
\hline 2029 & $11.8 \%$ & $21.4 \%$ & $54.5 \%$ \\
\hline 2030 & $11.8 \%$ & $23.0 \%$ & $58.0 \%$ \\
\hline 2031 & $11.8 \%$ & $24.3 \%$ & $60.9 \%$ \\
\hline 2032 & $11.9 \%$ & $25.5 \%$ & $63.4 \%$ \\
\hline 2033 & $11.9 \%$ & $26.4 \%$ & $65.5 \%$ \\
\hline 2034 & $11.9 \%$ & $27.2 \%$ & $67.1 \%$ \\
\hline 2035 & $11.9 \%$ & $27.8 \%$ & $68.4 \%$ \\
\hline 2036 & $11.9 \%$ & $28.3 \%$ & $69.4 \%$ \\
\hline 2037 & $11.9 \%$ & $28.7 \%$ & $70.2 \%$ \\
\hline 2038 & $11.9 \%$ & $29.0 \%$ & $70.9 \%$ \\
\hline 2039 & $11.9 \%$ & $29.2 \%$ & $71.4 \%$ \\
\hline 2040 & $11.9 \%$ & $29.4 \%$ & $71.7 \%$ \\
\hline 2041 & $11.9 \%$ & $29.5 \%$ & $72.0 \%$ \\
\hline 2042 & $11.9 \%$ & $29.6 \%$ & $72.3 \%$ \\
\hline 2043 & $11.9 \%$ & $29.7 \%$ & $72.4 \%$ \\
\hline 2044 & $11.9 \%$ & $29.8 \%$ & $72.6 \%$ \\
\hline 2045 & $11.9 \%$ & $29.8 \%$ & $72.7 \%$ \\
\hline
\end{tabular}

